\title{
Nutrient concentrations in runoff from different manure amended fields of the tropics under natural rainfall conditions ${ }^{1,2}$
}

\author{
Sandra L. Ortega-Achury ${ }^{3}$, Gustavo A. Martinez-Rodriguez ${ }^{4 *}$, \\ David Sotomayor-Ramírez ${ }^{5}$ and Miguel A. Muñoz-Muñoz ${ }^{5}$ \\ J. Agric. Univ. P.R. 91(3-4):101-115 (2007)
}

\begin{abstract}
Excessive nutrient losses from agricultural soils represent a major source of surface water contamination. In this study we quantified concentrations of total Kjeldahl nitrogen (TKN), dissolved and total phosphorus (DP, TP), and dissolved organic carbon (DOC) in runoff from two animal farm operations of Puerto Rico. The farms, one dairy and one poultry, represented typical conditions (i.e., topography, ecological zone, management system) of these production systems. Two fields were selected for the runoff studies on each farm, and two runoff collectors were installed in each field. Runoff samples were collected under natural rainfall conditions. The average phosphorus concentration in runoff from the poultry fields $(5.87 \mathrm{mg}$ TP/ $\mathrm{L}, 4.82 \mathrm{mg} \mathrm{DP} / \mathrm{L}$ ) was significantly greater than that observed from the dairy fields (2.29 mg TP/L, $1.79 \mathrm{mg}$ DP/L). Dissolved phosphorus concentrations represented more than $90 \%$ of the total $\mathrm{P}$ concentrations on both farms, a situation that may exacerbate the impact on receiving water bodies. Average DP concentrations exceeded $1 \mathrm{mg} / \mathrm{L}$, a limit proposed for the regulation of runoff $P$ concentrations from agricultural lands, in $70 \%$ of the runoff events at the dairy farm, and $100 \%$ of the events at the poultry farm. The magnitude of the nutrient concentrations on both farms was significantly affected by the time lapse between the manure applications and the first precipitation event. Nutrient concentrations in runoff samples were also significantly affected by rainfall depth.
\end{abstract}

Key words: runoff, water quality, nutrients, animal farm operations

\section{RESUMEN}

Concentración de nutrientes en la escorrentía de diferentes predios del trópico enmendados con residuos animales bajo condiciones de lluvia natural

${ }^{1}$ Manuscript submitted to the Editorial Board 24 October 2006.

${ }^{2}$ Funding for this study was obtained through a grant by USEPA Region 2 . We appreciate the collaboration of José L. Guzmán, Onilda Santana, Vidal Santiago, Ramón Aponte, Francisco Castro, and the farm owners in this project.

${ }^{3}$ Former Graduate Student, Agronomy and Soils Department, College of Agricultural Sciences, University of Puerto Rico-Mayagüez Campus.

${ }^{4}$ Professor, Agronomy and Soils Department, College of Agricultural Sciences, University of Puerto Rico- Mayagüez Campus. *For Correspondence: tavomarti@hotmail.com

${ }^{5}$ Professor, Agronomy and Soils Department, College of Agricultural Sciences, University of Puerto Rico. 
La pérdida excesiva de nutrientes de suelos agrícolas representa una fuente primaria de contaminación de los cuerpos de agua. En este estudio se cuantificaron las concentraciones de nitrógeno total Kjeldahl (NTK), fósforo total y disuelto (PD, PT), y carbón orgánico disuelto (COD) en la escorrentía de dos fincas productoras de animales de Puerto Rico. Las fincas, una vaquería y una avícola, son representativas de las condiciones típicas (i.e., topografía, zona ecológica, sistema de manejo) de estos sistemas de producción. En cada finca se seleccionaron dos predios para estudios de escorrentía y en cada predio se instalaron dos fraccionadores de escorrentía. Se recolectaron muestras de escorrentía generadas por eventos de lluvia natural. La concentración promedio de fósforo en la escorrentía de los predios avícolas (5.87 mg TP/L, $4.82 \mathrm{mg}$ PD/L) fue significativamente mayor que la observada en los predios de la vaquería (2.29 $\mathrm{mg} \mathrm{PT} / \mathrm{L}, 1.79 \mathrm{mg} \mathrm{PD} / \mathrm{L}$ ). La concentración de PD representó cerca del $90 \%$ de la concentración de PT observada en ambas fincas, situación que puede agravar el impacto en las aguas circundantes. La concentración de PD promedio excedió $1 \mathrm{mg} / \mathrm{L}$, límite propuesto para controlar la escorrentía de fósforo de predios agrícolas, en $70 \%$ de los eventos de escorrentía en el caso de la vaquería y en un $100 \%$ de los casos en la finca avícola. La magnitud de las concentraciones en ambas fincas se afectó significativamente por el lapso de tiempo transcurrido entre la aplicación de los residuos orgánicos y el primer evento de lluvia. La concentración de nutrientes en la escorrentía también se afectó significativamente con la profundidad de la lámina de lluvia.

Palabras clave: escorrentía, calidad de agua, nutrientes, fincas de producción animal

\section{INTRODUCTION}

The contamination of water bodies and associated problems are considered one of the greatest obstacles towards the sustainability of the human population in the twenty-first century. Nearly half of the population in developing countries is exposed to contaminated water, increasing the risk of water borne diseases (United Nations, 2003). In the United States, more than 3.12 million lake hectares and 433,329 river and stream kilometers are impaired (USEPA, 2000). Agriculture is listed as the major source of pollution of $48 \%$ of the impaired river and stream kilometers and $41 \%$ of the impaired lake area (USEPA, 2000). In Puerto Rico, it is estimated that $67 \%$ of the river kilometers being monitored are impaired. In addition, $99 \%$ of the total lake area does not meet the water quality standard for dissolved oxygen (DO) (PREQB, 2003).

Diverse studies indicate that eutrophication of water bodies dramatically accelerates in watersheds associated with high proportions of animal farm operations (USEPA, 1999; Klatt et al., 2003). In Puerto Rico, dairy and broiler production are two of the most important agricultural commodities, generating nearly $35 \%$ of the gross agricultural income (Department of Agriculture, 2003). The dairy and broiler farms produce great amounts of manure and litter that are typically land-applied to agricultural fields. Nutrient application rates in these fields frequently exceed crop uptake needs. This condition has resulted in the 
accumulation of nutrients to levels that can represent a threat to surrounding waters. Martínez et al. (2002) evaluated the phosphorus (P) status of different fields of 22 animal farm operations ( 11 dairy and 11 poultry farms) of Puerto Rico. Eighty percent of the soil samples analyzed exceeded the local agronomical critical soil P level $(32 \mathrm{mg} \mathrm{P} / \mathrm{kg}$ Olsen; Muñiz, 1992). The average soil $P$ level (Olsen) of poultry farms $(150 \mathrm{mg} / \mathrm{kg}$ ) was significantly higher than that of dairy farms $(90 \mathrm{mg} /$ $\mathrm{kg}$ ). Sotomayor et al. (2001) evaluated nutrient concentration trends from 1989 to 1997 for 11 rivers of the island. The authors indicated that four of the rivers had median P concentrations in excess of $0.1 \mathrm{mg} \mathrm{P} / \mathrm{L}$, a level suggested as critical for the prevention of eutrophication in rivers (Parry, 1998). Twenty-five percent of the water samples for the remaining seven rivers exceeded said threshold.

Recent efforts to control nutrient losses from agricultural farms focus on $\mathrm{P}$, since limnological studies have identified this nutrient as the most common limiting factor for algae growth in rivers and lakes (Vollenweider, 1976; Correll, 1998). A number of studies have shown that losses of dissolved phosphorus (DP) in runoff from agricultural farms are highly correlated with the soil test P (STP) content of the soils (Daverde et al., 2003; Andraski et al., 2003). The time lapse between manure application and the first rainfall event producing runoff has also been found determinant in the extent of nutrient losses from the field. For instance, Pierson et al. (2001) reported that on farms under poultry manure application, the DP concentration losses in runoff reached values as great as $19 \mathrm{mg} / \mathrm{L}$ in an event that occurred immediately after the application. The authors observed a gradual decrease in DP concentration losses in subsequent events. Nitrogen exhibits a behavior different from that of phosphorus, showing a more rapid decrease in runoff concentration after its application. This difference has been attributed to the $\mathrm{N}$ transformation processes that occur in the soil, such as volatilization, leaching, and denitrification (Sharpe and Harper, 2002; Pierson et al., 2001).

Although diverse studies have been undertaken to identify the factors of greater incidence in the loss of nutrients from experimental plots, few studies have been conducted at field level under natural rainfall conditions. The objective of this study was to quantify the nutrient concentrations (TKN, TP, DP, DOC) in runoff from fields amended with dairy and poultry manure, under typical management and natural rain conditions.

\section{MATERIALS AND METHODS}

A more detailed description of the experimental framework and methodology used in this study can be found in Ortega-Achury (2005). 
Study sites. The study was carried out on two farms representing the primary agricultural production industries in Puerto Rico, dairy and broiler farms. Two fields with a history of manure application were evaluated on each farm. Throughout the study all fields were managed by the farmers according to normal practices without interference from the research team. The dairy farm (fields that receive dairy manure) is located in the municipality of San Sebastian, in the west central region of Puerto Rico. Soils on this farm correspond to the Soller series (clayey, mixed, active, isohyperthermic, shallow Typic Haprendolls) with a $12 \%$ average slope. Fields 1 and 2 received liquid dairy manure at the rate of 1,387 and $492 \mathrm{~m}^{3} / \mathrm{yr}$, respectively, with corresponding $\mathrm{N}$ and $\mathrm{P}$ loading rates of $248 \mathrm{~kg}$ N/ha/yr and $71 \mathrm{~kg}$ P/ha/yr in field $1 ; 72 \mathrm{~kg} \mathrm{~N} / \mathrm{ha} / \mathrm{yr}$ and $21 \mathrm{~kg} \mathrm{P} / \mathrm{ha} / \mathrm{yr}$ in field 2 (Table 1). The poultry farm (fields under broiler litter application) is located in the municipality of Corozal, in the central mountainous region of Puerto Rico. The soils correspond to the Consumo and Naranjito series (fine, mixed, semiactive, isohyperthermic Typic Haplohumults) with slopes of 25 and $32 \%$ for field 1 and 2 , respectively. Both fields received poultry manure applications at the rate of $4,536 \mathrm{~kg} / \mathrm{yr}$, with a $\mathrm{P}$ loading rate of $284 \mathrm{~kg} \mathrm{P} / \mathrm{ha} / \mathrm{yr}$ (Table 1). Farmers followed regularly scheduled application practices established in their nutrient management plans prepared by the USDA-NRCS, Caribbean Area Office.

TABLE 1.-Grazing dates and manure application dates and rates during the study period.

\begin{tabular}{|c|c|c|c|c|}
\hline Farm & $\begin{array}{c}\text { Field } \\
\text { area }\left(\mathrm{m}^{2}\right)\end{array}$ & $\begin{array}{l}\text { Grazing } \\
\text { date }\end{array}$ & $\begin{array}{c}\text { Manure } \\
\text { application date }\end{array}$ & $\begin{array}{l}\text { Manure } \\
\text { applied }\end{array}$ \\
\hline Dairy & $\begin{array}{l}1 \\
(11,198.2)\end{array}$ & $\begin{array}{l}19 \text { to } 28 \text { Aug. } 2003 \\
18 \text { to } 29 \text { Sept. } 2003 \\
6 \text { to } 19 \text { Nov. } 2003 \\
16 \text { to } 27 \text { Jan. } 2004 \\
10 \text { to } 25 \text { May } 2004\end{array}$ & $\begin{array}{l}9 \text { Sept. } 2003 \\
15 \text { Oct. } 2003 \\
25 \text { Nov. } 2003 \\
03 \text { May } 2004 \\
27 \text { Apr. } 2004\end{array}$ & $\begin{array}{l}268.5 \mathrm{~m}^{3} \\
134.2 \mathrm{~m}^{3} \\
268.5 \mathrm{~m}^{3} \\
357.9 \mathrm{~m}^{3} \\
357.9 \mathrm{~m}^{3}\end{array}$ \\
\hline Dairy & $\begin{array}{l}2 \\
(13,708.4)\end{array}$ & $\begin{array}{l}6 \text { to } 19 \text { Sept. } 2003 \\
18 \text { to } 25 \text { Nov. } 2003 \\
5 \text { to } 21 \text { Apr. } 2004\end{array}$ & $\begin{array}{r}15 \text { Oct. } 2003 \\
3 \text { May } 2004 \\
27 \text { Apr. } 2004\end{array}$ & $\begin{array}{l}134.2 \mathrm{~m}^{3} \\
179.0 \mathrm{~m}^{3} \\
179.0 \mathrm{~m}^{3}\end{array}$ \\
\hline Poultry & $\begin{array}{l}1 \\
(2,554.1)\end{array}$ & $\begin{array}{l}4 \text { to } 24 \text { Aug. } 2003 \\
27 \text { Sept. to } 6 \text { Oct. } 2003 \\
14 \text { Nov. to } 5 \text { Dec. } 2003 \\
10 \text { to } 30 \text { March } 2004\end{array}$ & 10 May 2004 & $\begin{array}{l}4536 \mathrm{~kg} / \mathrm{ha} \\
4536 \mathrm{~kg} / \mathrm{ha}\end{array}$ \\
\hline Poultry & $\begin{array}{l}2 \\
(3,230.1)\end{array}$ & $\begin{array}{l}4 \text { to } 24 \text { Aug. } 2003 \\
27 \text { Sept. to } 6 \text { Oct. } 2003 \\
14 \text { Nov. to } 5 \text { Dec. } 2003 \\
10 \text { to } 30 \text { March } 2004\end{array}$ & 10 May 2004 & $\begin{array}{l}4536 \mathrm{~kg} / \mathrm{ha} \\
4536 \mathrm{~kg} / \mathrm{ha}\end{array}$ \\
\hline
\end{tabular}


Soil sampling and analysis. Sampling grids with cells of $25 \mathrm{~m}^{2}$ (poultry fields) and $100 \mathrm{~m}^{2}$ (dairy fields) were developed, depending on the field size, to assess soil test P status. In each field, $35 \%$ of the cells were randomly sampled. A minimum of five sub-samples were taken on each cell at a $0-$ to $7-\mathrm{cm}$ depth. The samples were air dried, sieved $(<2$ $\mathrm{mm}$ ), and analyzed for $\mathrm{pH}$ and conductivity, using 1:1 soil to water ratio (Soil Survey Laboratory, 1996). The samples were also analyzed for Olsen extractable P (Olsen, 1982), determined colorimetrically using the Murphy-Riley method (Murphy and Riley, 1962).

Runoff plots. The major representative points of off-field overland flow on each field were identified by using topographical maps generated with the global positioning system (GPS). Based on these points two runoff collectors (Franklin et al., 2001) were installed in each field. These collectors separated the runoff in two fractions: 1/100 and 1/10 of the total. The collection systems consisted of two polypropylene bottles of 25-L capacity. A rain gauge was installed at each farm to register and measure each precipitation event during the evaluation period (August 2003 to May 2004).

Runoff collection and analysis. Runoff samples were collected in $1 \mathrm{~L}$ polypropylene bottles after each precipitation event, preserved to $\mathrm{pH}<2\left(\mathrm{H}_{2} \mathrm{SO}_{4}\right)$ in the field and stored frozen $\left(4^{\circ} \mathrm{C}\right)$ until analyses. Each sample was analyzed for TP, and TKN. A $100-\mathrm{ml}$ sub-sample was filtered using a $0.45-\mu \mathrm{m}$ cellulose filter for the DP and DOC analyses. Total Kjeldahl nitrogen was analyzed after digestion with a sulfuric acid-potassium sulfate solution using the BRANN + LUEBBE autoanalyzer $3^{6}$ (Method No 351.3-USEPA, 1999). Total phosphorus was determined colorimetrically after persulfate digestion (Method 365.2USEPA, 1999). Dissolved phosphorus was measured in the filtered sub-sample (Method 365.1-USEPA, 1999) using Murphy-Riley methods. Dissolved organic carbon was determined by quantifying the absorbance (280 nm) using a DU-520 Beckman UV/VIS spectrophotometer (Chin et al., 1994). An additional sample, with no addition of $\mathrm{H}_{2} \mathrm{SO}_{4}$ was collected for suspended solids (SS) analysis; SS was determined by weighing the residue retained on a $0.45-\mu \mathrm{m}$ glass fiber filter dried to constant weight at $105^{\circ} \mathrm{C}$ (EPA method \# 160.2).

Statistical analyses. The data were logarithm $\left(\log _{10}\right)$-transformed to conform to normality and homogeneity of variance. Since many of the $\mathrm{P}$ concentrations were $<1 \mathrm{mg} / \mathrm{L}$ data were transformed by adding 1

\footnotetext{
${ }^{6}$ Trade names in this publication are used only to provide specific information. Mention of a trade name does not constitute a warranty of equipment or materials by the $\mathrm{Ag}$ ricultural Experiment Station of the University of Puerto Rico, nor is this mention a statement of preference over other equipment or materials.
} 
$\mathrm{mg} / \mathrm{L}$ to the concentration and determining the logarithm of that sum, so that no negative values were present in the data set. Differences in nutrient concentrations between experimental sites (manure type) were evaluated by the Tukey's test at the $5 \%$ level of significance.

\section{RESULTS AND DISCUSSION}

Soil test phosphorus (STP). Soil test phosphorus values for the dairy farm varied from 4.48 to $402.61 \mathrm{mg} \mathrm{P} / \mathrm{kg}$ (average $41 \mathrm{mg} / \mathrm{kg}$ ). In the case of the poultry farm, STP fluctuated between 13.43 and 407.52 $\mathrm{mg} \mathrm{P} / \mathrm{kg}$ (average $152 \mathrm{mg} / \mathrm{kg}$ ) (Table 2; Figure 1). According to the environmental soil P categories established for Puerto Rico (Sotomayor et al., 2004), $10 \%$ of the soil samples in the poultry manure plots had values within the medium category (12 to $35 \mathrm{mg} \mathrm{P} / \mathrm{kg}$ ); $32 \%$ ranked in the high category ( 36 to $123 \mathrm{mg} \mathrm{P} / \mathrm{kg}$ ); $24 \%$ in the very high category (124 to $179 \mathrm{mg} \mathrm{P} / \mathrm{kg}$ ); and $34 \%$ in the extremely high category ( $>179 \mathrm{mg} \mathrm{P} / \mathrm{kg}$ ). On the dairy farm, $60 \%$ of the soil samples were in the low to medium categories, $37 \%$ in the high category, $2 \%$ in the very high category, and only $1 \%$ in the extremely high category. The results agree with findings of Martínez et al. (2002), who indicated that the elevated soil P levels and steep topography characteristic of poultry farms in Puerto Rico represent a significant threat to the integrity of the surrounding waters.

Runoff. Throughout the study (August 2003 to May 2004), 14 and 17 runoff events were generated from the fields at the dairy and poultry farms, respectively. Two hundred forty-eight water samples were collected and analyzed for nutrients, and suspended solids. There were no significant differences (ANOVA; $\mathrm{P} \leq 0.05$ ) in nutrient concentrations between water samples from the $1 / 10$ and $1 / 100$ fractions of each collector, or between the two runoff collectors in each field. Consequently results from each event were averaged out for analyses, and are presented as such.

Nutrient losses from dairy manure fields. The average nutrient composition of runoff in the dairy fields is presented in Table 3 . These values include two atypical events that occurred on 27 April and 3 May

TABLE 2.-Soil test $P$ (Olsen) for fields under dairy and poultry manure application.

\begin{tabular}{lclrrrr}
\hline & & & & & \multicolumn{2}{c}{ Soil test P - Olsen (mg/kg) } \\
\cline { 5 - 7 } Farm & Field & Soil series & $\begin{array}{c}\text { Number } \\
\text { of samples }\end{array}$ & Average & Minimum & Maximum \\
\hline Dairy & 1 & Soller & 109 & 46.36 & 4.48 & 402.61 \\
Dairy & 2 & Soller & 57 & 35.00 & 5.28 & 105.12 \\
Poultry & 1 & Naranjito & 27 & 164.38 & 13.43 & 407.52 \\
Poultry & 2 & Consumo & 54 & 139.53 & 15.13 & 273.93 \\
\hline
\end{tabular}




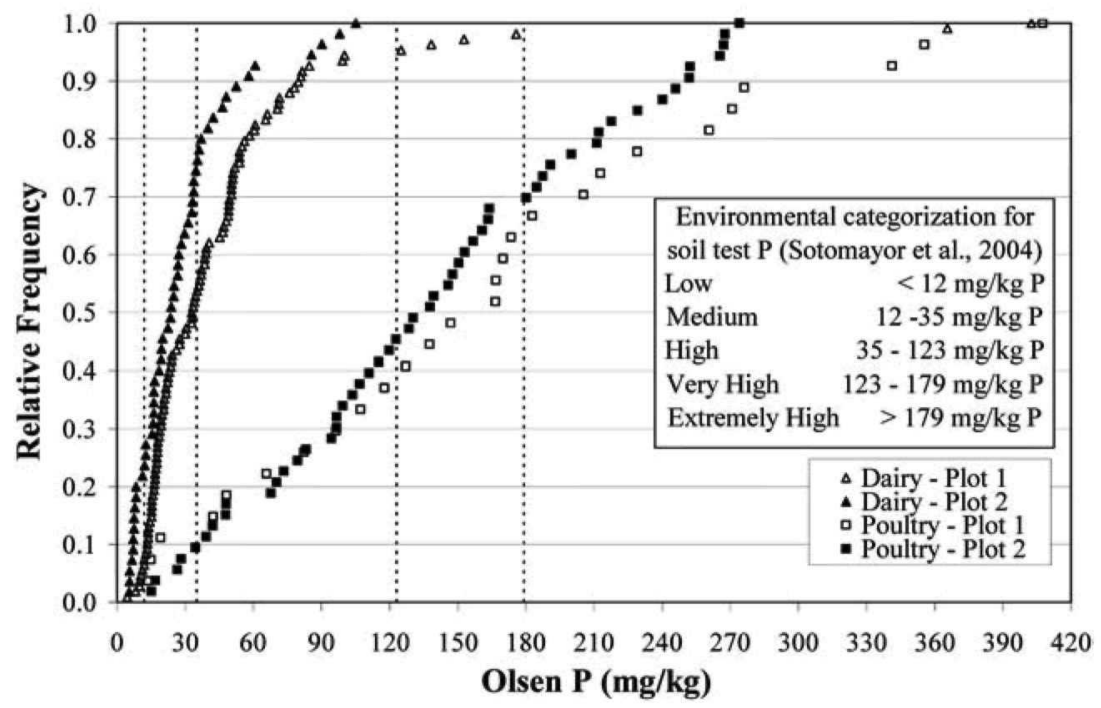

FIGURE 1. Soil (Olsen) P distribution at both farms [categorization according to Sotomayor et al. (2004)].

2004. On these dates, manure was applied for over two hours in excess of the time stipulated on the manure management program $(1.26 \mathrm{~h} /$ day/plot), causing direct runoff of the irrigation effluent into the collection systems.

The average concentrations of TP, DP, TKN, DOC, and SS for the two atypical events were $22.5 \mathrm{mg} / \mathrm{L}, 2.46 \mathrm{mg} / \mathrm{L}, 128.73 \mathrm{mg} / \mathrm{L}, 127.65 \mathrm{mg} / \mathrm{L}$, and $1.35 \mathrm{mg} / \mathrm{L}$, respectively. It is evident that under these atypical conditions, nutrient concentrations in runoff are much greater than under normal conditions (Table 3 ). These events may be indicative of situations generated during storm events where the storage capacity of the oxidation lagoons is exceeded, thus resulting in direct effluent losses.

Excluding the atypical events, the highest $\mathrm{P}$ concentration in runoff from field 1 ( $8.93 \mathrm{mg} \mathrm{TP} / \mathrm{L}$ and $5.61 \mathrm{mg} \mathrm{DP} / \mathrm{L}$ ) occurred in the runoff event of 9 September 2003, the afternoon of the dairy manure application. The importance of the time between the manure application and the first rainfall event is evident when comparing these results with $\mathrm{P}$ concentrations in field 2. In the latter, no dairy manure was applied on that day (September 9) and runoff concentrations were significantly lower (1.40 mg TP/L and $1.00 \mathrm{mg} \mathrm{DP} / \mathrm{L}$ ) (Figure 2). These results coincided with reports from other research (Sharpley, 1997; Gilley and Rise, 2000; Kleinman and Sharpley, 2003; Schroeder et al., 2004) indicating 
TABLE 3.-Average composition of selected nutrients in runoff collected at the dairy manure-amended farm.

\begin{tabular}{lrrrrr}
\hline & \multicolumn{2}{c}{ Average of total events } & & \multicolumn{2}{c}{ Average $^{1}$} \\
\cline { 2 - 3 } \cline { 5 - 6 } Component & Field 1 & Field 2 & & Field 1 & Field 2 \\
\hline TP-mg/L & 5.26 & 4.89 & & $2.79 \mathrm{a}^{2}$ & $1.56 \mathrm{~b}$ \\
$\mathrm{DP}-\mathrm{mg} / \mathrm{L}$ & 2.20 & 1.38 & & $2.11 \mathrm{a}$ & $1.24 \mathrm{~b}$ \\
$\mathrm{TKN}-\mathrm{mg} / \mathrm{L}$ & 20.71 & 23.79 & & $5.97 \mathrm{a}$ & $2.99 \mathrm{~b}$ \\
$\mathrm{DOC}-\mathrm{mg} / \mathrm{L}$ & 41.11 & 47.38 & & $27.72 \mathrm{a}$ & $32.96 \mathrm{a}$ \\
$\mathrm{SS}-\mathrm{g} / \mathrm{L}$ & 0.23 & 0.28 & & $0.11 \mathrm{a}$ & $0.03 \mathrm{~b}$ \\
$\mathrm{pH}$ & 7.14 & 7.62 & & $7.00 \mathrm{a}$ & $7.59 \mathrm{~b}$ \\
\hline
\end{tabular}

${ }^{1}$ Excluding events of 27 April and 3 May 2004.

${ }^{2}$ Different letters indicate significant differences between fields ( $p \leq 0.05$ ).

that the time between manure application and the initial first runoff event is crucial in terms of the magnitude of P losses. The DP concentrations measured in the runoff varied from 0.13 to $5.61 \mathrm{mg} / \mathrm{L}$. This amount is somewhat lower than the value reported by Kleinman et al. (2002) under simulated rainfall conditions ( 0.7 to $9.5 \mathrm{mg} / \mathrm{L})$. The DP concentration in $70 \%$ of the events exceeded the critical value sug-

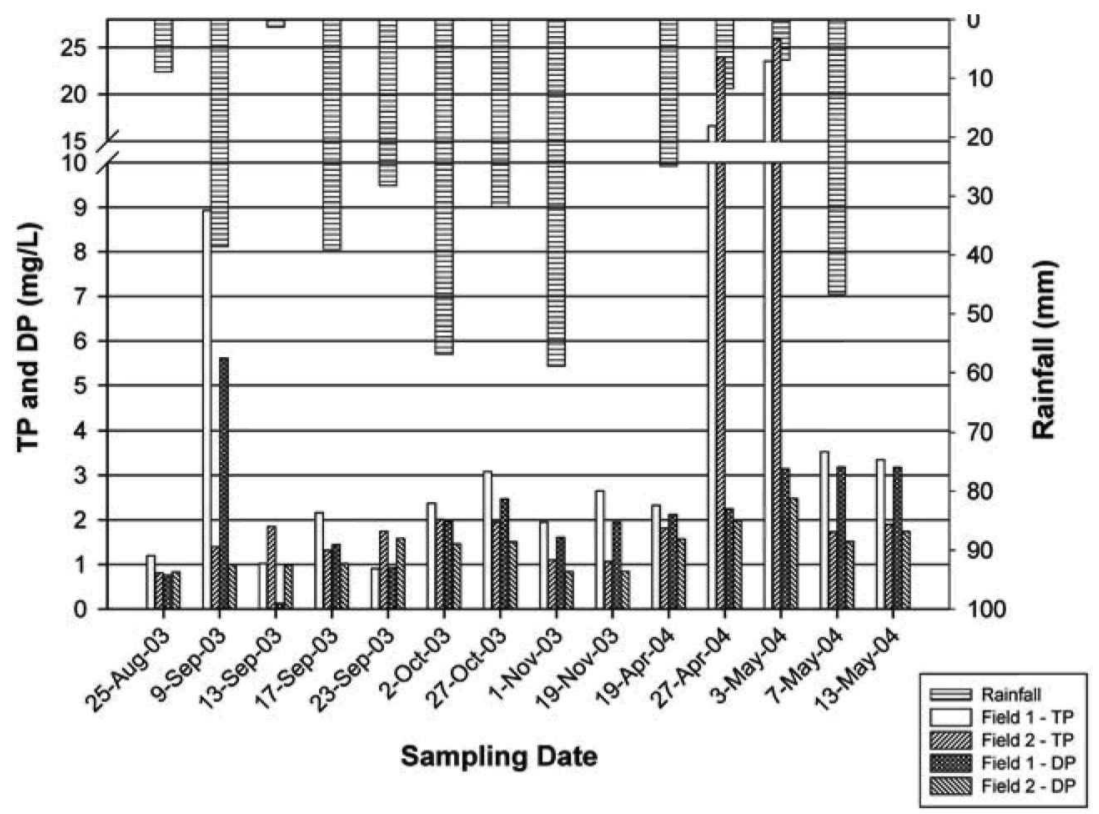

FIGURE 2. Runoff'TP and DP concentration from fields receiving dairy manure. 
gested by the USEPA (1986) for the regulation of the DP concentrations in runoff from agricultural fields ( $1 \mathrm{mg} / \mathrm{L}$ ).

Similar to P, greater TKN concentrations in field 1 (26.50 mg TKN/ L) occurred during the event of 9 September 2003, immediately after manure application (Figure 3). Although concentrations were high in events occurring immediately after the manure application, a significant reduction was observed in subsequent events, mainly due to $\mathrm{N}$ transformation losses (e.g., volatilization). Sharpe and Harper (2002) indicated that in cultivated fields receiving liquid manure, $35 \%$ of the $\mathrm{N}$ loss comes in the form of $\mathrm{NH}_{3}-\mathrm{N}$ and only $1.5 \%$ in the form of $\mathrm{N}_{2} \mathrm{O}-\mathrm{N}$. A significant increment in the TKN concentrations $(13.18 \mathrm{mg} / \mathrm{L}$ ) (Figure 3 ) was observed during the 19 November 2003 event for field 1 . This event coincided with a 14-day grazing period of 42 cows in this field, thus suggesting that the increase in TKN concentration in runoff was due to the direct contribution of manure and urine coming from these animals. The average DOC concentration in runoff was 27.72 and 32.96 $\mathrm{mg} / \mathrm{L}$ for fields 1 and 2 , respectively. These values are higher than the average $20 \mathrm{mg} / \mathrm{L}$ maximum concentration observed in surface water by Chapman (1992). Sediment concentrations in runoff were low, with values of 0.11 and $0.03 \mathrm{~g} / \mathrm{L}$ for fields 1 and 2 , respectively, probably because of the extensive vegetative cover in both fields ( $>90 \%)$.

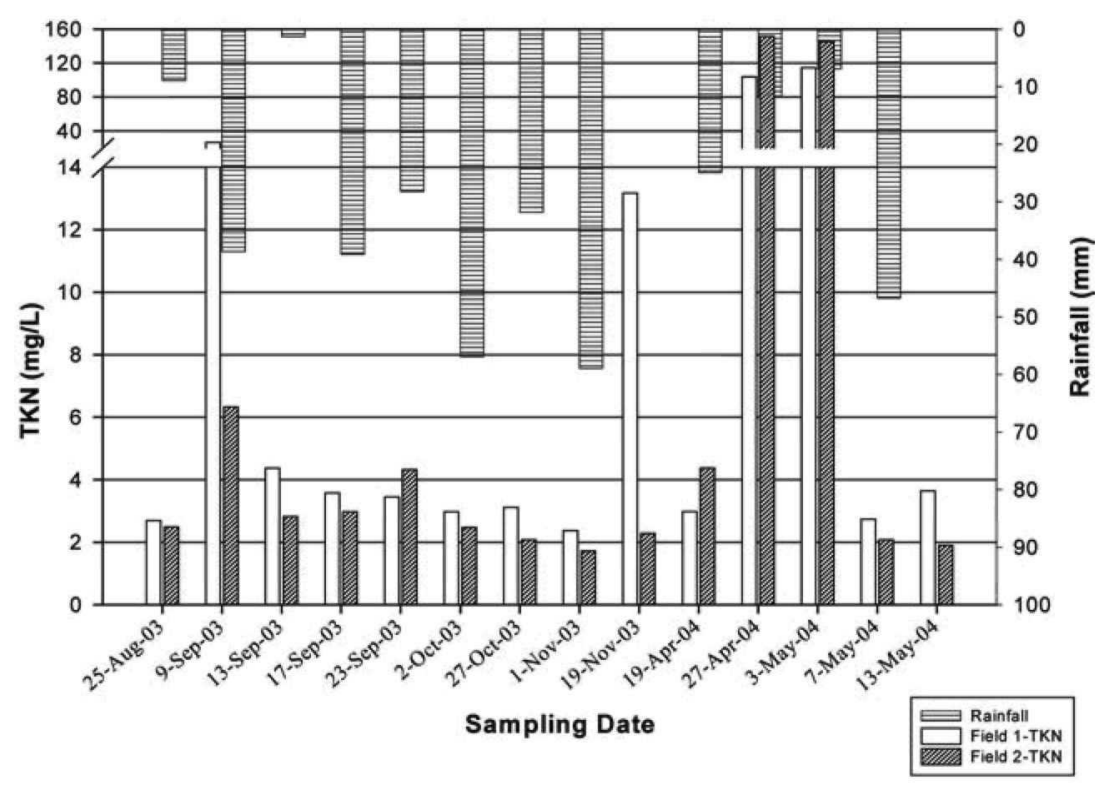

FIGURE 3. Runoff TKN concentration from fields receiving dairy manure. 
Nutrient losses from poultry manure fields. The average concentration of nutrients, suspended solids and $\mathrm{pH}$ in runoff from the poultry manure field are shown in Table 4 . A statistically significant difference $(\mathrm{P} \leq 0.05)$ was observed between the average TP and DP runoff concentrations of field 1 relative to those of field 2. Also, a significant interaction was found between the time lapse after manure application and precipitation depth. Greater P runoff concentrations were observed in field 1 than in field 2 , in concordance with the greater soil available Olsen P status of this field ( $164.38 \mathrm{mg} \mathrm{P} / \mathrm{kg}$ ) relative to that of field 2 (139.53 mg P/kg). The high DP and TP concentrations in runoff from these fields confirm the direct relation between the initial soil test (STP) and off-field P losses. It is important to note, however, that the timing between manure applications and rainfall occurrence may also have an effect on the relationship between STP and P in runoff.

Concentrations of DP in runoff exceeded the $1 \mathrm{mg} / \mathrm{L}$ USEPA threshold in all events (Figure 4). Pierson et al. (2001) showed DP concentrations greater than $1 \mathrm{mg} / \mathrm{L}$ even 19 months after manure application, thus suggesting that inputs from manure become a high potential source of contamination with effects that could last a long time after application. The $\mathrm{P}$ concentration experienced a gradual decrease with time after application (Figure 4). Similar results have been reported by other researchers, who emphasize the importance that the time lapse between the application of manure and the initiation of the precipitation events has on the extent of nutrient losses in runoff (Sharpley, 1997; Kleinman et al., 2002; Gilley et al., 2002).

Maximum TKN concentration (12.04 and $7.57 \mathrm{mg} / \mathrm{L}$, for fields 1 and 2 , respectively) in runoff water occurred immediately after poultry manure application. However, these concentrations decreased rapidly in later events (16 and 27 May 2004) (Figure 5). This decrease may be the result of nitrogen losses through volatilization and leaching. Similar results were reported by Pierson et al. (2001), who indicated that the

TABLE 4.-Average composition of selected nutrients in runoff collected at the poultry manure-amended farm.

\begin{tabular}{lcr}
\hline Component & Field 1 & Field 2 \\
\hline TP-mg/L & $6.21 \mathrm{a}^{1}$ & $5.42 \mathrm{~b}$ \\
$\mathrm{DP}-\mathrm{mg} / \mathrm{L}$ & $5.38 \mathrm{a}$ & $4.18 \mathrm{~b}$ \\
$\mathrm{TKN}-\mathrm{mg} / \mathrm{L}$ & $4.11 \mathrm{a}$ & $4.11 \mathrm{a}$ \\
$\mathrm{DOC}-\mathrm{mg} / \mathrm{L}$ & $29.86 \mathrm{a}$ & $26.17 \mathrm{a}$ \\
$\mathrm{SS}-\mathrm{g} / \mathrm{L}$ & $0.10 \mathrm{a}$ & $0.12 \mathrm{a}$ \\
$\mathrm{pH}$ & $5.75 \mathrm{a}$ & $5.76 \mathrm{a}$ \\
\hline
\end{tabular}

${ }^{1}$ Different letters in a row indicate significant differences between fields $(\mathrm{p} \leq 0.05)$. 


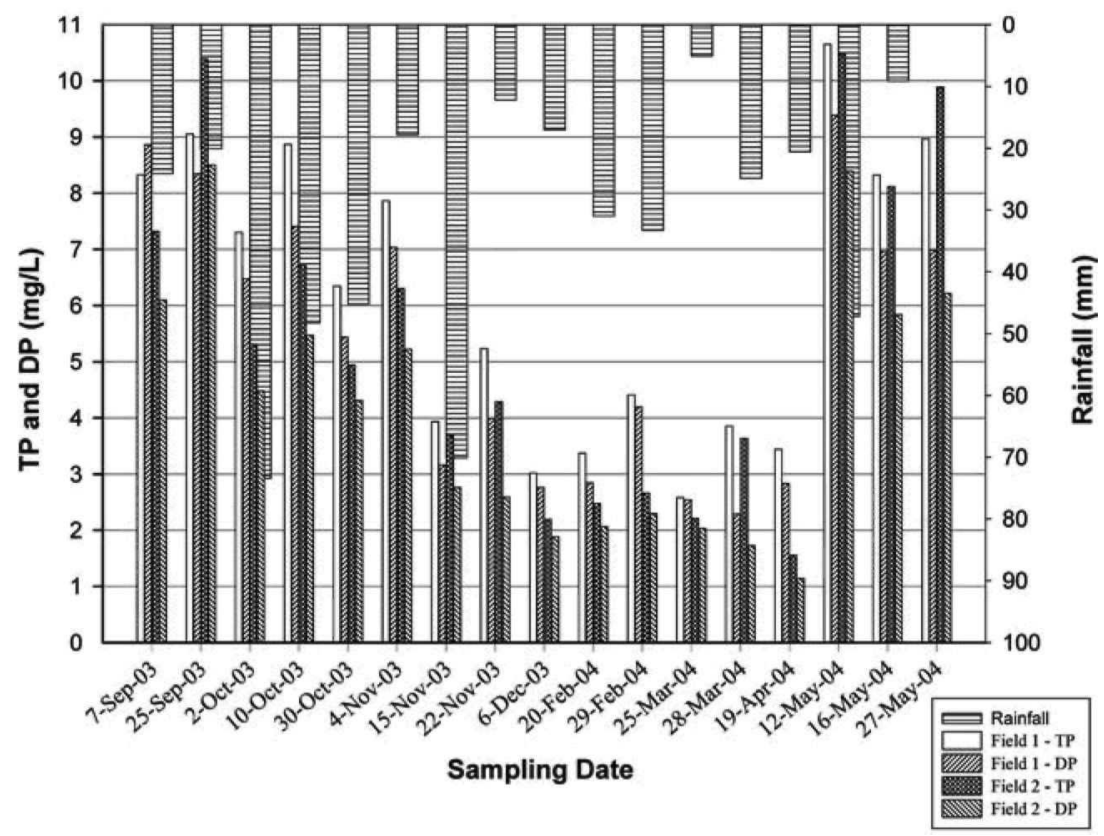

FIGURE 4. Runoff TP and DP concentration from fields receiving poultry manure.

rapid decrease in $\mathrm{NH}_{4}$ concentrations was due mostly to volatilization, uptake or mineralization.

The event of 22 November 2003 is a special case in that high P and $\mathrm{N}$ concentrations in runoff were observed despite a small precipitation event $(12.2 \mathrm{~mm})$. Although reasons for such an incident are not clear, a possible explanation is that pasture was high (approx. $70 \mathrm{~mm}$ ) at the time of the rain event, all of which may have reduced the volume of runoff and increased the concentration of nutrients in the laminar flow.

In terms of DOC, greater concentration $(86 \mathrm{mg} / \mathrm{L})$ occurred a few days after the manure application, 12 May 2004. The same behavior was reported by Vories et al. (2001), who observed concentrations of 101 $\mathrm{mg} / \mathrm{L}$ in an event that occurred nine days after the manure application. Average concentrations of DOC were 29.86 and $26.17 \mathrm{mg} / \mathrm{L}$ for fields 1 and 2 , respectively. These values are much higher than those reported by Vories et al. (2001) from a cotton field, and greater than the range of concentrations generally observed in surface waters ( 1 to $20 \mathrm{mg} / \mathrm{L}$ ) (Chapman, 1992).

Comparison between dairy and poultry farms. Significant differences were found between the two farms in regard to the 


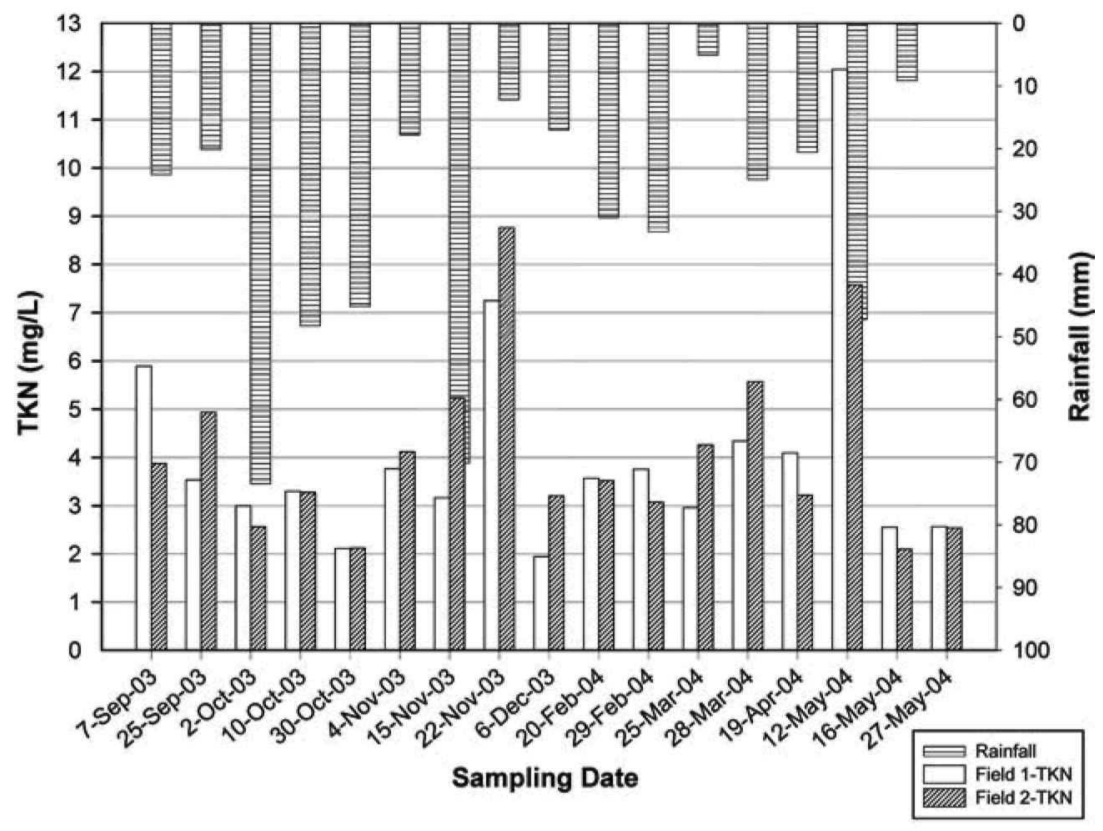

Figure 5. Runoff'TKN concentration from fields receiving poultry manure.

concentration of TP, DP, and SS in runoff (Table 5). Phosphorus concentrations in runoff were greater from fields with poultry manure application than those receiving dairy manure. These differences are attributed mainly to the rate of nutrient application (e.g., an average of $54 \mathrm{~kg} \mathrm{P} / \mathrm{ha} / \mathrm{yr}$ for that dairy farm vs. $284 \mathrm{~kg} / \mathrm{P} / \mathrm{ha} / \mathrm{yr}$ for the poultry farm), to the form of the application [dry surface (poultry) vs. liquid surface (dairy)], and to the greater slope of the poultry farm (25 to $32 \%$ ) compared to that of the dairy farm (12\%), all of which favors the offfield transport of nutrients. In the case of $\mathrm{P}$, it is important to consider the variability of the different $P$ fractions in manure, particularly the dissolved fraction. Differences in the relative composition of the manure regarding this fraction can significantly affect the extent of $P$ concentration in runoff water from a field (Kleinman and Sharpley, 2003). Another determining factor is the $P$ status of the soils. Average STP values in runoff from the poultry manure fields were significantly greater $(152 \mathrm{mg} / \mathrm{kg})$ than those from the dairy manure fields $(41 \mathrm{mg} /$ $\mathrm{kg}$ ). There was a strong positive correlation between the TP and DP runoff concentrations on both farms. The DP fraction represented close to $92 \%$ of the TP losses, values in accord with those reported by Ed- 
TABLE 5.-Comparison of average selected nutrient runoff composition between farms.

\begin{tabular}{llccccc}
\hline Farm & TP & DP & TKN & DOC & SS $(\mathrm{g} / \mathrm{L})$ & $\mathrm{pH}$ \\
\hline Dairy $^{1}$ & $2.29 \mathrm{a}^{2}$ & $1.79 \mathrm{a}$ & $4.57 \mathrm{a}$ & $30.13 \mathrm{a}$ & $0.08 \mathrm{a}$ & $7.27 \mathrm{a}$ \\
Poultry & $5.87 \mathrm{~b}$ & $4.82 \mathrm{~b}$ & $4.12 \mathrm{a}$ & $29.58 \mathrm{a}$ & $0.22 \mathrm{~b}$ & $5.76 \mathrm{~b}$ \\
\hline
\end{tabular}

${ }^{1}$ Average excluded atypical events of 27 April and 3 May 2004.

${ }^{2}$ Different letters in a column indicate significant differences between farms $(p \leq 0.05)$.

wards and Daniel (1993), Sharpley et al. (1999), Sauer et al. (2000), and Gaston et al. (2003). This finding is critical since the dissolved fraction is considered readily available for algae use.

\section{CONCLUSIONS}

Nutrient concentrations in runoff from fields receiving manure applications from two different types of animal farm operations were determined. Average runoff concentrations were $2.29 \mathrm{mg} \mathrm{TP} / \mathrm{L}, 1.79 \mathrm{mg}$ $\mathrm{DP} / \mathrm{L}, 4.57 \mathrm{mg} \mathrm{TKN} / \mathrm{L}$, and $30.13 \mathrm{mg} \mathrm{DOC} / \mathrm{L}$ for the dairy manure treated fields. In the case of the poultry manure treated fields, average concentrations were $5.87 \mathrm{mg} \mathrm{TP} / \mathrm{L}, 4.82 \mathrm{mg} \mathrm{DP} / \mathrm{L}, 4.12 \mathrm{mg} \mathrm{TKN} / \mathrm{L}$, and $29.58 \mathrm{mg} \mathrm{DOC} / \mathrm{L}$. Greater nutrient concentrations were observed in runoff from events occurring immediately ( $<5$ days) after manure application. Runoff $\mathrm{P}$ concentrations exhibited a slow gradual decrease after manure application; in contrast, nitrogen concentrations decreased rapidly, mainly because of volatilization and leaching. Dissolved phosphorus concentrations represented more than $90 \%$ of the total $\mathrm{P}$ concentrations on both farms, a situation that may aggravate the impact on receiving waters. Average DP concentrations exceeded $1 \mathrm{mg} / \mathrm{L}$ in $70 \%$ of the runoff events at the dairy manure amended farm, and $100 \%$ of the events at the poultry manure amended farm. The poultry farm exhibited higher runoff concentrations of TP, $\mathrm{DP}$, and suspended solids than those of the dairy farm. This finding is related to the higher application loads, to form of application (dry surface vs. liquid surface) and to the greater slope (12\% vs. 25 to $32 \%$ ) of the fields from the poultry farm relative to that of the dairy fields. The results lead us to conclude that poultry farms pose a greater risk of surface water contamination in Puerto Rico than dairy farms.

\section{LITERATURE CITED}

Andraski, T. W. and L. G. Bundy, 2003. Relationships between phosphorus levels in soil and runoff in corn production systems. J. Env. Qual. 32:310-316.

Chapman, D., 1992. Water Quality Assessments. Ed. Chapman \& Hall Ltd., London, Great Britain. pp. 51-119. 
Chin, Y. P., G. Aiken and E. O'Loughlin, 1994. Molecular weight, polydispersivity, and spectroscopic properties of aquatic humic substances. Environ. Sci. Tech. 28:1853.

Correll, D. L., 1998. The role of phosphorus in the eutrophication of receiving waters: A review. J. Environ. Qual. 28: 261-266

Daverde, I. C., A. N. Kravchenko, R. G. Hoeft, E. D. Nafziger, D. G. Bullock, J. J. Warren and L. C. Gonzini, 2003. Phosphorus runoff: effect of tillage and soil phosphorus levels. J. Environ. Qual. 32:1436-1444.

Department of Agriculture of Puerto Rico, 2003. Ingreso Bruto Estimaciones para el año 2002-2003. Department of Agriculture of Puerto Rico, 5 pp.

Edwards, D. R. and T. C. Daniel, 1993. Effects of poultry litter application rate and rainfall intensity on quality of runoff from fescue grass plots. J. Environ. Qual. 22:361365.

Franklin, D. H., M. L. Cabrera, J. L. Steiner, D. M. Endale and W. P. Miller, 2001. Evaluation of percent flow captured by a small in-field runoff collector. Am. Soc. Ag. Eng. 44(2):551-554.

Gaston, L. A., C. M. Drapcho, S. Tapadar and J. L. Kovar, 2003. Phosphorus runoff relationships for Louisiana Coastal Plain soils amended with poultry litter. J. Environ. Qual. 32:1422-1429.

Gilley, J. E. and L. M. Rise, 2000. Runoff and soil loss as affected by the application of manure. Trans. of Am. Soc. of Agric. Eng. 43 (6):1583-1588.

Gilley, J. E., L. M. Rise and B. Eghball, 2002. Managing runoff following manure application. J. Soil Water Conserv, 57(6):530-533.

Klatt, J. G., A. P. Mallarino, J. A. Downing, J. A. Kopaska and D. J. Wittry, 2003. Soil phosphorus, management practices, and their relationship to phosphorus delivery in the Iowa Clear Lake agricultural watershed. J. Env. Qual. 32:2140-2149.

Kleinman, P. J., A. N. Sharpley, G. M. Barton and G. F. Elwinger, 2002. Effect of mineral and manure phosphorus sources on runoff phosphorus. J. Environ. Qual. 31:20262033.

Kleinman, P. J. and A. N. Sharpley, 2003. Effect of broadcast manure on runoff phosphorus concentrations over successive rainfall events. J. Environ. Qual. 32:1072-1081.

Martínez, G. A., D. Sotomayor-Ramírez and J. A. Castro, 2002. Application of the Caribbean P Index to soils receiving organic amendments. J. Agric. Univ. P.R. 86:145-154.

Muñiz, O., 1992. Uso de fertilizantes en Puerto Rico: Enfoques prácticos; guía técnica. University of Puerto Rico, Agricultural Extension Service, Mayagüez, P.R. 26 pp.

Murphy, J. and J. P. Riley, 1962. A modified single solution method for determination of phosphate in natural water. In: Page, E. L., R. H. Miller and R. D. Keeney. 1988. Methods of Soil Analysis. Part. 2. Chemical and microbiological properties. American Society of Agronomy. INC. Soil. Sci. Soc. Am. INC. Publisher. Wisconsin. p. 1159.

Olsen, S. R., 1982. Phosphorus. In: Methods of Soil Analysis. Part 2, 2nd ed; ASA and SSSA: Madison, WI. 403-430 pp.

Ortega-Achury, S., 2005. Validación del índice de fósforo del Caribe y evaluación de prácticas de manejo de desechos orgánicos en fincas de producción animal de Puerto Rico. www.grad.uprm.edu/tesis/ortegaachury.pdf

Parry, R., 1998. Agricultural Phosphorus and Water Quality: A U.S. Environmental Protection Agency Perspective. J. Environ. Qual. 27:258-261.

Pierson, S. T., M. L. Cabrera, G. K. Evanylo, H. A. Kuykendall, C. S. Hoveland, M. A. McCann and L. T. West, 2001. Phosphorus and ammonium concentrations in surface runoff from grasslands fertilized with broiler litter. J. Environ. Qual. 30:17841789.

Puerto Rico Environmental Quality Board, 2003. Puerto Rico water quality inventory and list of impaired waters. Integrated report 305(b)/303 (d). PREQB. Puerto Rico. 
Sauer, T. J., T. C. Daniel, D. J. Nichols, C. P. West, P. A. Moore and G. L. Wheeler, 2000. Runoff water quality from poultry litter treated pasture and forest sites. $J$. Environ. Qual. 29:515-521.

Schroeder, P. D., D. E. Radcliffe, M. L. Cabrera and C. D. Belew, 2004. Relationship between soil test phosphorus and phosphorus in runoff: Effects of soil series variability. J. Environ. Qual. 33:1452-1463.

Sharpe, R. R. and L. A. Harper, 2002. Nitrous oxide and ammonia fluxes in a soybean field irrigated with swine effluent. J. Environ. Qual. 31:524-532.

Sharpley, A. N., 1997. Rainfall frequency and nitrogen and phosphorus in runoff from soil amended with poultry litter. J. Environ. Qual. 26:1127-1132.

Sharpley, A. N., 1999. Managing phosphorus for agriculture and the environment. Publications distribution center, The Pennsylvania State University. 2-3 pp.

Sharpley, A. N., T. Daniel, T. Sims, J. Lemunyon, R. Stevens and R. Parry, 1999. Agricultural phosphorus and eutrophication. United States Department of Agriculture (USDA), Agricultural Research Service (ARS-149).

Soil Survey Laboratory (SSL), 1996. Soil survey laboratory methods manual. Soil survey investigations report №. 42, version 3.0. USDA. $693 \mathrm{pp}$.

Sotomayor, D., G. Martínez and L. J. Olivieri, 2001. Phosphorus status of stream waters in Puerto Rico: 1989-1997. J. Agric. Univ. P.R. 85:1-15.

Sotomayor, D., G. Martínez, O. Santana, R. Mylavarapu and J. Guzmán, 2004. Phosphorus soil test for environmental assessment in subtropical soils. Comm. in Soil Sci.Plant Anal. 35:1485-1503.

United Nations, 2003. The UN World Water Development Report "Water for People, Water for Life". United Nations publication, Sales No. E.03.II.A.2.

U.S. Environmental Protection Agency, 1986. Quality criteria for water. Office of water regulation and standards. EPA-440/5-86-001. May 1986.

U.S. Environmental Protection Agency, 1999. EPA Methods and guidance for analysis of water. CD-ROM ver. 2.0. USEPA, Washington, D.C.

U.S. Environmental Protection Agency, 2000. National Water Quality Inventory-Report. Available at http://www.epa.gov/305b/2000report/ (accessed 15 Nov. 2003; verified 6 Sept. 2005). USEPA, Washington, D.C.

Vollenweider, R. A., 1976. Advances in defining critical loading levels of phosphorus in Lake eutrophication. Mem. Ist. Ital. Idriobiol. 33:53-83.

Vories, E. D., T. A. Costello and R. E. Glover, 2001. Runoff from cotton fields fertilized with poultry litter. Trans. of Am. Soc. of Agric. Eng. 44(6):1495-1502. 